Abstracta Iranica Abstracta Iranica

Revue bibliographique pour le domaine irano-aryen

Volume 29 | 2008

Comptes rendus des publications de 2006

\title{
Pāye-gozārān-e națr-e jadīd-e fārsī. Tehrān, Našr-e Ney, 1384/2005, 316 p. [Les fondateurs de la prose persane moderne]
}

Ève Feuillebois-Piérunek

\section{(2) OpenEdition \\ Journals}

Édition électronique

URL : http://journals.openedition.org/abstractairanica/31762

DOI : 10.4000/abstractairanica.31762

ISSN : 1961-960X

Éditeur :

CNRS (UMR 7528 Mondes iraniens et indiens), Éditions de l'IFRI

\section{Édition imprimée}

Date de publication : 15 mai 2008

ISSN : 0240-8910

\section{Référence électronique}

Ève Feuillebois-Piérunek, « Pāye-gozārān-e națr-e jadìd-e fārsī. Tehrān, Našr-e Ney, 1384/2005, 316 p. [Les fondateurs de la prose persane moderne] », Abstracta Iranica [En ligne], Volume 29 | 2008, document 344, mis en ligne le 15 septembre 2008, consulté le 26 septembre 2020. URL : http:// journals.openedition.org/abstractairanica/31762; DOI : https://doi.org/10.4000/abstractairanica. 31762

Ce document a été généré automatiquement le 26 septembre 2020.

Tous droits réservés 
Pāye-gozārān-e națr-e jadīd-e fārsī. Tehrān, Našr-e Ney, 1384/2005, 316 p. [Les fondateurs de la prose persane moderne]

Ève Feuillebois-Piérunek

1 Version persane non remaniée de Modern Persian Prose Literature, Cambridge University Press, 1966.

INDEX

Thèmes : 11.1.2. Littérature persane moderne

\section{AUTEURS}

ÈVE FEUILLEBOIS-PIÉRUNEK

Sorbonne Nouvelle-Paris III - Mondes iranien et indien 